\title{
O(S) ESPAÇO(S) PÚBLICO(S) NUMA CIDADE DESIGUAL E SEGREGADA
}

\author{
Rafael de Aguiar Arantes *
}

\begin{abstract}
Este artigo analisa os usos do(s) espaço(s) público(s) na vida urbana contemporânea, discutindo sua relevância e sua capacidade de expressar diversidade e engendrar intersubjetividades. Para isso, busca-se discutir a validade das teses que indicam a existência de um processo de diluição/restrição dos espaços públicos, analisando sua dinâmica na cidade do Salvador, Bahia, Brasil, e considerando as transformações urbanas recentes, através de revisão da literatura, coleta de dados secundários e realização de entrevistas com diversos citadinos. O artigo conclui que as transformações contemporâneas vêm favorecendo o avanço de formas de privatização e autossegregação, restringindo os usos dos espaços públicos. Porém, não se pode falar da morte desses espaços em Salvador, uma vez que seus usos sobrevivem, ainda que sejam premidos por seu caráter heterogêneo, desigual, segregado e fragmentado, situação ensejada por processos de privatização e mercantilização, violência e medo, além de diferentes formas de disputas, distinções e competições.

Palavras-chave: Espaço público. Sociabilidade Urbana. Privatização. Segregação. Salvador.
\end{abstract}

\section{INTRODUÇÃO}

Este trabalho analisa os usos atuais do(s) espaço(s) público(s) na vida urbana contemporânea discutindo sua relevância e sua capacidade de expressar diversidade e engendrar intersubjetividades. Mais especificamente, o artigo analisa tais processos através de um estudo empírico na cidade de Salvador. Para isto, considera-se que, desde meados do século XX, desenvolve-se um conjunto de reflexões sobre as características e as dimensões da vida pública na modernidade (Arendt, 2008; Habermas, 2003; Sennett, 1988). Em todas elas, de maneira mais ou menos direta, a condição urbana aparece como um fenômeno atrelado à dimensão pública da vida social, de modo que a cidade aparece como um lugar onde se constituiu determinada esfera ou cultura pública, seja na antiguidade ou nos primeiros séculos da modernidade. Essa compreensão se asso-

\footnotetext{
* Universidade Federal da Bahia (UFBA). Faculdade de Filosofia e Ciências Humanas (FFCH)

Estrada de São Lázaro, no 197 - Federação - CEP: 40.210730, Salvador - Bahia - Brasil. rafaelarantes13@gmail.com http://orcid.org/0000-0002-3953-9340
}

cia à de outros autores como Simmel (2005), Weber (1999) e Wirth (1979) que, por terem escrito anteriormente sobre as cidades modernas, identificaram características que foram apropriadas pelos debates sobre o público e o espaço público. A cidade moderna passou a ser associada, pelos trabalhos contemporâneos, ao surgimento do cosmopolitismo, da civilidade, da tolerância às diferenças e de ideias importantes como as de urbanidade e civitas, incluindo cidadania e até democracia, elementos associados a ideais como o de Res Pública (Duhau, 2001; Gomes, 2008; Mongin, 2009; Netto, 2012).

Tais discussões sobre a vida pública nas cidades se aprofundaram com as transformações ocorridas na passagem para o século XXI. Para muitos desses autores, se as cidades modernas se constituíram como espaços onde, em determinado período, surgiu uma "esfera pública burguesa” (Habermas, 2003) ou uma "cultura" - assim como uma "geografia" - pública (Sennett, 1988), nas últimas décadas estaria se processando uma dissolução do espaço público tradicional (Caldeira, 2000; Duhau, 2001; Davis, 2009; Dammert, 2013; Sennett, 
1988). ${ }^{1}$ No espaço urbano construído, uma das maiores expressões desse processo é a difusão de enclaves fortificados, empreendimentos imobiliários que se conformam como "espaços privatizados, fechados e monitorados para residência, consumo, lazer e trabalho" (Caldeira, 2000, p. 211). Detentores da fortificação como uma de suas principais características, esses enclaves constituem uma das mais recentes (e extremadas) estratégias de segregação, na medida em que valorizam o que é privado e restrito; são demarcados e isolados fisicamente por muros e grades; são controlados muitas vezes por guardas armados e avançados sistemas de segurança, que definem as regras de inclusão e exclusão; embora possam se situar em qualquer lugar, impõem uma barreira física e simbólica de apartação em relação ao seu entorno; e incentivam a homogeneidade social, valorizando a vivência entre pessoas iguais e seletas (Caldeira, 2000).

A proliferação desses enclaves e o aprofundamento dos processos de privatização urbana estariam engendrando uma tendência de “fuga dos males da cidade" (Arantes, 2011), um abandono cada vez maior dos espaços públicos e uma recusa da convivência interclassista e da constituição de laços de sociabilidade baseados na alteridade (Bauman, 2009). Para Davis (2009, p. 236-241) a "fusão do urbanismo, da arquitetura e do aparato policial num único esforço abrangente de segurança cria um efeito fortaleza" que emerge não como $\vec{\delta}$ "uma inadvertida falha do planejamento, mas - como uma estratégia socioespacial deliberada". A rejeição do outro parece se tornar uma das consequências centrais dessa nova condição urbana. Conviver com os estranhos e dii. ferentes se torna penoso, "[...] convertendo a

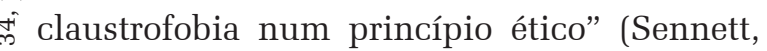
1988, p. 378). A fuga das interações e dos espaços heterogêneos (ou seja, da própria cidade em direção às comunidades) destrói a própria essência da urbanidade, qual seja, "que os homens podem agir juntos sem a compulsão de

${ }^{1}$ Para uma revisão detalhada dessa discussão teórica, ver Arantes (2019). serem os mesmos” (Sennett, 1988, p. 318).

Transformações na escala e na forma urbana das cidades contemporâneas (como o privilégio aos veículos em detrimento dos pedestres, a redução da diversidade de usos em muitos espaços, a suburbanização e a primazia da arquitetura defensiva), assim como a própria incapacidade e omissão do Estado no que se refere a uma política voltada aos espaços públicos, em geral degradados e abandonados, contribuiriam também para o processo de esvaziamento desses espaços. Para Caldeira (2000), a esfera pública na cidade moderna cede espaço a um novo modelo assentado na tensão, separação, discriminação e suspeição, no qual são reafirmados hierarquias e privilégios sociais. Segundo Duhau (2001, p. 57-58, tradução nossa), isso é particularmente verdadeiro nas metrópoles periféricas como as latino-americanas. Nessas cidades, de um lado, os grupos médios e altos enfrentam a crise do espaço público através de uma "feudalização" e uma "condominização da cidade" baseadas num "pseudocomunitarismo defensivo (às vezes, muito agressivo)"; e, de outro lado, as camadas populares usam o espaço público "colonizando-o através de suas práticas econômicas, de mobilidade, de consumo e recreação e impõe[m] sobre ele sua própria estética" (Duhau, 2001, p. 62, tradução nossa).

De acordo com Ramírez-Kuri (2008), em cidades segregadas e marcadas por processos de modernização, onde a desigualdade e a pobreza tiveram dimensões relevantes, a construção do público mostra tendências contrapostas: de um lado, sua diluição, fragmentação e exclusão e, de outro, o ressurgimento de novas formas de relação, comunicação e participação. Para ela, há uma diversidade de espaços públicos que exibem fenômenos discrepantes de sociabilidade e conflito, modernização e massificação, mercantilização e informalidade, inovação, segregação e desigualdade, assim como insegurança, violência e medo. Assim, as teses sobre a restrição do espaço público vêm sendo questionadas e problematizadas a partir de diversas 
perspectivas. Sem aprofundar essa discussão, vale salientar a multiplicidade dos questionamentos: a) a existência real de um espaço público verdadeiramente amplo em algum período histórico, especialmente fora do contexto europeu, de onde provêm as discussões sobre a constituição do espaço público moderno; b) a complexidade e a diversidade existentes dentro da própria ideia de "espaços públicos"; c) a existência de tendências múltiplas e até contraditórias no que tange à situação dos espaços públicos em variados contextos urbanos; d) o foco das análises no comportamento dos grupos de renda média e alta; e e) as transformações e deslocamentos observados nesses espaços nos últimos anos, que acarretariam em outro modelo de espaço público e não no seu desaparecimento ou restrição (Andrade e Baptista, 2013; Salcedo Hansen, 2002; Leite, 2009; Ramírez-Kuri, 2008).

Apesar das críticas, essa discussão permanece como uma das mais influentes do campo dos estudos urbanos, aparecendo, de maneira direta ou tangencial, em diversos trabalhos sobre as cidades contemporâneas. Segundo Ramírez-Kuri (2008), o espaço público é o lugar onde melhor se pode compreender as relações estabelecidas entre as pessoas e a cidade, assim como as formas de organização ou desintegração da vida comum. Por isso, a reflexão sobre essa questão a partir de uma pesquisa empírica se mostra relevante. Considerando tal problemática, o presente artigo analisa em que aspectos ou até que ponto o fenômeno da restrição dos espaços públicos pode ser visto na cidade de Salvador, capital do estado da Bahia e atualmente a quarta maior cidade do Brasil. O primeiro aspecto a ser analisado refere-se aos critérios que definem os espaços públicos. O conceito de espaço/esfera pública tem uma longa tradição na filosofia e nas ciências sociais e foi utilizado pelos teóricos muitas vezes de formas distintas. Também existem diferentes acepções do conceito na linguagem corrente, já que faz referência a eventos e locais abertos (em contraposição àqueles fechados), às opiniões chamadas de "públicas" ou ao próprio Estado entendido como Poder Público (Habermas, 2003). Isto complexifica a sua utilização, pois a ideia de público pode se remeter aos espaços físicos de uso coletivo, a determinados padrões de convivência social e sua relação com a diversidade, ou mesmo a relações que envolvem um discurso político, relativas à participação e às disputas pelo poder.

Segundo Joseph (2002), a expressão "espaço público" designa fenômenos que não são exatamente iguais: a esfera pública e o espaço público urbano. Nas palavras de Paquot (2009), espaço público é um singular cujo plural - espaços públicos - não lhe corresponde. Isto porque existem duas tradições que pensaram os espaços públicos: a europeia, voltada para uma compreensão associada à urbanidade e à democracia, e a tradição norte-americana, ligada aos estudos urbanos da Escola de Chicago. O espaço público analisado pela primeira tradição evoca o lugar do debate político, da confrontação de opiniões, uma forma de comunicação, de circulação de ideias e, em última instância, uma prática democrática. A formação no plural, comum à segunda tradição, desce ao nível da rua e do espaço concreto para interrogar sobre sua natureza, sobre sua relação com as atividades cotidianas e ordinárias (Joseph, 2002; Paquot, 2009). Apesar da diferença entre os termos, Paquot chama a atenção para o fato de que ambos têm em comum a ideia de partilha, colaboração, relação, troca e circulação. Não são fenômenos iguais e, portanto, não podem ser assimilados um ao outro, mas também possuem profunda relação, o que justifica uma análise que leve as duas ideias a uma confluência.

Tentando superar as dificuldades de conceituação com vistas à operacionalização de uma pesquisa empírica, o presente trabalho passou a entender o(s) espaço(s) público(s) urbano(s), em termos ideais-típicos, como aqueles lugares que incorporam pelo menos quatro dimensões, ainda que as três primeiras adquiram maior centralidade na presente análise. São conformados por: a) uma geografia pública (ou seja, são espaços físicos de acessibilidade 
ampla e irrestrita, que não se fecham a priori à diversidade e às trocas sociais); b) possuem certa vitalidade (isto é, são efetivamente utilizados, permitem usos variados e expressam uma relativa diversidade social); c) são lugares de ação, interação e relações de sociabilidade urbana - espaços onde se desenvolvem rituais e práticas, um ballet interacional (Bordreuil, 2002), onde a estética da conversação e do consenso concertado se transfere para o sistema da rua, conformando uma "intersubjetividade prática" (Joseph, 1999). No que tange a essa dimensão, utiliza-se de modo mais ampliado a compreensão de sociabilidade de Simmel (2002): a forma lúdica da socialização, um tipo puro de relação sem quaisquer propósitos, interesses ou objetivos além da interação em si mesma, composta por jogos de sociedade que se baseiam no ato de participar (Frúgoli Jr., 2007; Simmel, 2002); e d) o(s) espaço(s) público(s) urbano(s) incorporariam uma dimensão associada a sua conformação enquanto palco e cena de movimentos políticos, ou seja, quando se conformam como substratos da mobilização, participação e discussão política (Harvey, 2014).

Considerando as características da pesquisa que orienta este trabalho, foi fundamental desenvolver uma metodologia que englobasse uma triangulação entre diferentes métodos-fontes-técnicas (Pereira, 1991). Inicialmente, foi realizada uma ampla revisão da literatura sobre a constituição do espaço urbano, do es¿ิ paço público e das relações de sociabilidade na - cidade do Salvador. Foram realizadas também dez entrevistas com informantes qualificados, ¿ como observadores privilegiados dos processos Fे de transformação da cidade nos últimos anos, $\dot{2}$ assim como autoridades públicas, especialmenfi te aquelas vinculadas à gestão dos espaços de

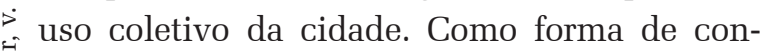
textualizar a disponibilidade desses espaços e seus usos em Salvador, foram coletados dados secundários que se transformaram nos diversos mapas apresentados ao longo do trabalho. A pesquisa contou ainda com observação direta e participante em espaços públicos referenciais da cidade, escolhidos de modo a garantir certa representatividade qualitativa das suas diferentes áreas, e da realização de trinta entrevistas semiestruturadas com distintos moradores de Salvador, especialmente com jovens que vivenciam a cidade contemporânea.

A seleção dos entrevistados se deu de modo qualitativo, intencional e não-probabilístico, através da técnica da "bola de neve", e foi interrompida quando as respostas alcançaram certo nível de saturação. Para maior riqueza quanto à experiência de vida na cidade, o trabalho buscou entrevistar pessoas diversas em termos de suas características sociais, principalmente no que concerne às dimensões de classe, escolaridade e local de moradia. As entrevistas foram transcritas e analisadas através da técnica de codificação, de forma que foram criados categorias e conceitos abstratos obtidos pelo agrupamento de ideias, eventos, acontecimentos, ações e interações (Strauss; Corbin, 2008, p. 104). Para tanto, foi utilizado como apoio o software de análise qualitativa Atlas TI, que mediou a construção de categorias dedutivas, derivadas das discussões teóricas e pressupostas na construção do instrumento, e indutivas, provenientes e captadas das experiências dos entrevistados. A partir desses dados, este trabalho pretende contribuir para a discussão sobre a dinâmica das cidades contemporâneas, especialmente no que tange aos seus espaços públicos.

\section{ABANDONO DOS ESPAÇOS PÚ- BLICOS E PRIVATIZAÇÃO URBA- NA EM SALVADOR}

A Cidade de Salvador, situada no estado da Bahia, Brasil, nunca teve um espaço público completamente aberto e plural, associado a práticas de tolerância, civilidade e urbanidade. Durante o período colonial, não havia relações igualitárias e amplas entre os grupos sociais em função da estratificação da sociedade, da escravidão e da dominação senhorial e mas- 
culina. Diferentemente das cidades europeias, que se constituíram num contexto de emancipação do sistema feudal e da formação de modelos de sociedade inspirados nos ideais iluministas, liberais e democráticos, Salvador, assim como as demais cidades coloniais brasileiras, serviu durante muito tempo aos objetivos de organização e controle do território nacional e das estratégias da colonização. Esse "sentido de cidade", parafraseando Caio Prado Júnior (2008) quando se refere ao sentido da colonização brasileira, continua influenciando a vida social e urbana da capital da Bahia. Ao longo de seu processo de modernização, a cidade do Salvador também não conseguiu garantir condições mais democráticas de vivência citadina e/ou participação política por conta de fatores como o autoritarismo vigente na sociedade e no Estado e a amplitude das desigualdades socioespaciais, com um acentuado processo de segregação.

Apesar disso, nos últimos anos os processos de privatização urbana têm se aprofundado, especialmente devido à proliferação de enclaves fortificados. No que tange à habitação, desde a década de 1990, tem havido uma expansão e diversificação significativas da incorporação de condomínios fechados em Salvador. Os novos empreendimentos chegam a ter mais de mil unidades e ofertam a centralização das atividades de trabalho, lazer e serviços. Nesta cidade, até alguns empreendimentos do programa de moradia popular Minha Casa, Minha Vida têm adotado a fórmula da fortificação (Arantes, 2011). Dese- jando convertê-los em "cidades blindadas dentro da cidade" (Amendola, 2000), a publicidade desses empreendimentos tenta marcar a sua diferença em meio à vida urbana. Numa dessas publicidades, apresentada na Figura 1, fica bastante explícita a oferta de um mundo individual e único, ou seja, uma antípoda do que Hannah Arendt (2008) considerou uma das dimensões mais básicas da esfera pública: o compartilhamento do interesse por um mundo comum, capaz de reunir os seres humanos na companhia uns dos outros e ao mesmo tempo evitar que eles colidam entre si.

\section{Figura 1 - Publicidade do Empreendimento Green Ville}

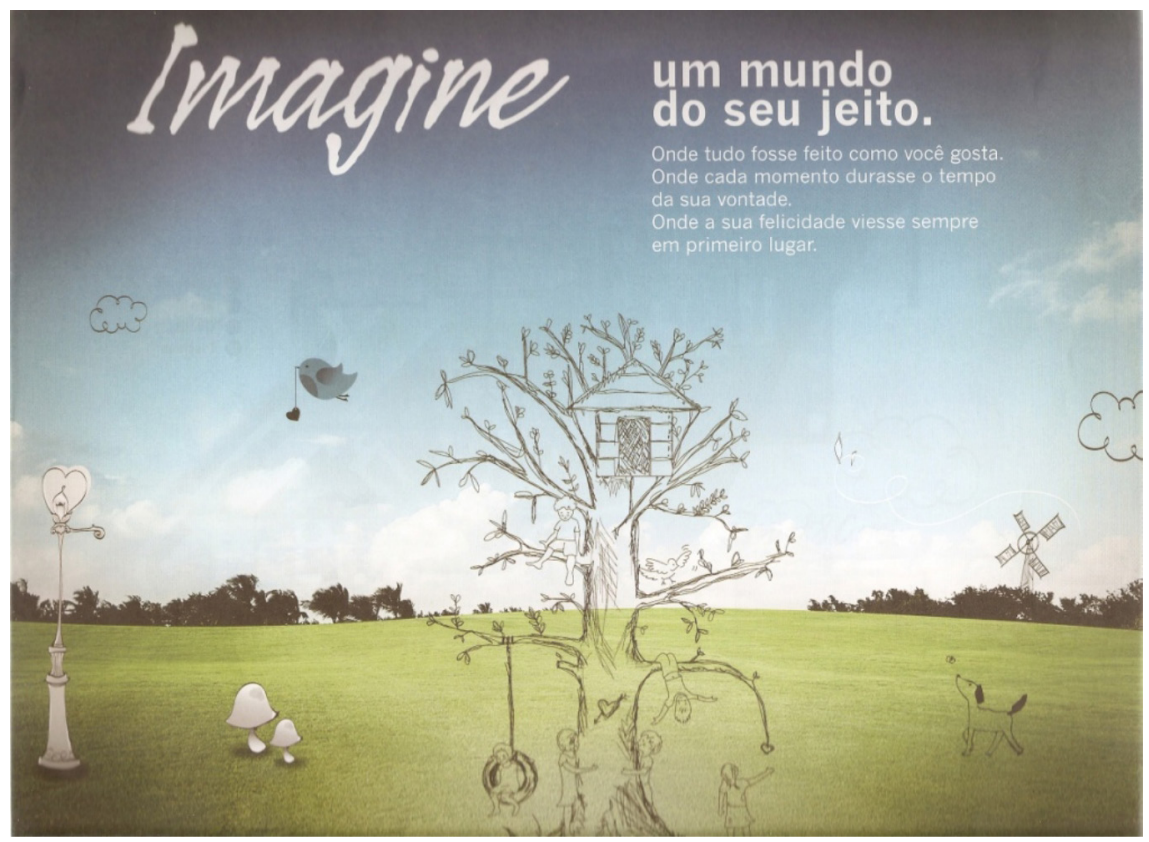

Fonte: Publicidade divulgada no Jornal A Tarde de 18 de novembro de 2012 
primeira evidência indica o relevante desinteresse e a desafeição por esses espaços, o que se expressa na falta de prática (no sentido de hábito) de frequentá-los. Alguns relatos são bastante ilustrativos dessa tendência:

Não, não costumo [frequentar], já fui, mas não é uma coisa comum. Tipo Parque da Cidade, Pituaçu? Não. [...] eu não acho tão chato, sabe, mas se eu chamasse meus amigos pra ir pro parque, eles iam ficar meio que, tipo, "a gente vai fazer que merda lá, vai sentar e...?” Segundo, sei lá, tipo, não tem tanta coisa assim pra fazer num parque e também eu acho perigoso, eu teria medo de ir. [...] [E praça?] E praça? Acho que não... Acho que a mesma coisa... Não tem tanta utilidade assim pra mim... (Q., 18 anos, estudante de cursinho, moradora do Costa Azul, bairro de perfil médio-alto).

[...] É difícil eu ir num parque. Porque falta em mim, como é que eu posso dizer, falta em mim esse processo de adquirir novos espaços, sempre se acostumar no mesmo. Até mesmo cinema é recente eu tá participando do cinema. Não é uma prática minha. A minha rotina sempre foi um barzinho com a galera, alguns colegas têm um carro, a gente sai pra tomar uma cerveja fora. (A., 24 anos, representante comercial/universitário, morador do bairro de Plataforma, bairro de perfil popular).

Nunca [fui em parque]. Fui umas duas vezes quando era menino, mas não vou atualmente. Porque é um lazer que não me apetece, eu não acho interessante. (R., 22 anos, estudante universitário, morador de Nazaré, bairro de perfil médio do centro tradicional).

Nunca fui não. Rapaz, na verdade, nunca ninguém me chamou, nunca pensei em ir assim. Na verdade eu acho a praia mais interessante, algo desse tipo, praia, clube, não tenho muito interesse em parque não, nem Parque de Pituaçu, Parque da Cidade. (P., 23 anos, vendedor, morador de Tancredo Neves, bairro de perfil popular).

Conforme destacou Serpa (2007), os espaços são apropriados de maneira seletiva e isso depende das identidades e das práticas dos fi grupos sociais. Neste aspecto, a disposição à utilização dos espaços programados para uso público em Salvador parece estar distante do universo simbólico e de práticas de variados moradores. Segundo o referido autor, alguns desses espaços estão alheios a diversos grupos sociais, especialmente às camadas populares, pela sua inacessibilidade física e principalmente simbó- lica, já que foram planejados para dialogar com códigos de condutas, práticas culturais e repertórios de camadas médias, de maior capital cultural. Não obstante, de acordo com os relatos, citadinos de grupos médios e altos são os menos afeitos à utilização desses espaços, uma vez que suas atividades de lazer são realizadas e suas relações de sociabilidade se expressam principalmente em espaços privados. Assim, mais do que não frequentar os espaços públicos, uma parcela significativa dos moradores de Salvador os evita. A sensação de insegurança e medo tem sido um dos principais motivos disto, especialmente entre grupos de camadas médias e altas, mas não restrito a eles. Alguns relatos ilustram tal evitação dos espaços públicos:

Esses espaços públicos que são literalmente abertos, que não tem uma coordenação direta, eles também não têm uma estrutura decente a oferecer... nem estrutura, nem segurança, ou estão danificados ou são muito perigosos [...] Não frequento muito porque as pessoas que eu ando não frequentam e quando eu penso em ir eu penso muito na segurança, fico preocupado. No Parque da Cidade mesmo, a vez que eu fui eu achei muito pouca a segurança, no lugar tem uma mata muito aberta e qualquer vacilo ali já foi. (J., 22 anos, fotógrafo/atendente de telemarketing, morador do Pelourinho, bairro histórico e atualmente de perfil popular).

Nunca fui no Parque da Cidade. Eu ia ao [Parque] Pituaçu quando era pequena, mas também parei de frequentar. [...] Deixei de frequentar por questões de segurança mesmo. Os dois, infelizmente, não são muito seguros. O parque da cidade eu nunca fui porque eu cresci com meu pai falando pra eu não ir porque tinha estupro, tinha isso, tinha aquilo... como eu nunca fui e eu cresci com essa imagem do parque, nunca tive vontade de ir. (D., 23 anos, estudante universitária, moradora da Pituba, bairro de perfil médio-alto).

O medo, algumas vezes, é resultado de experiências concretas de violência sofridas pelas pessoas ou ocorridas em espaços antes frequentados. Outros, no entanto, se baseiam em imaginários que representam os espaços públicos como lugares violentos, frequentados por agentes "portadores", por assim dizer, da violência: os grupos perigosos. Certa percepção de que a cidade mudou e que a violência contribuiu fortemente para isso está presente nos 
relatos de pessoas mais velhas que viveram em Salvador em décadas anteriores. Pereira (2013), por exemplo, identificou entre pais e mães moradores de condomínios verticais de perfil médio e alto um sentimento de perda do prazer de viver a cidade, de andar nas ruas. Alguns relatos coletados tanto pela referida autora quanto por este autor, são ilustrativos desse processo:

Meus filhos têm medo. Antônio tem 15 anos e, apesar dos 15 anos, Antônio ainda tem medo de andar sozinho, de andar solto na rua. É, quando a gente fala que, naquele tempo, com a idade que ele tem, 14, 15 anos, a gente voltava do colégio, ia pro colégio de ônibus, terminava a prova, não precisava que ninguém fosse pegar, porque a gente ia andando pro Campo Grande pegava o ônibus e voltava pra casa, parece absurdo, mas hoje é inviável (F.,41 anos, médico apud Pereira, 2013, p. 93-94).

O mundo lá fora é um mundo cão, né? É um mundo ‘cãozaço', então é... infelizmente a gente não pode se entocar aqui, e tem que viver mesmo a vida (M., 40 anos, médica apud Pereira, 2013, p. 98).

Meus filhos têm uma qualidade de vida que eu tinha quando era pequeno. O condomínio [fechado] resgata isso, lazer agregado a moradia e segurança. Uma infância sadia para meus filhos.Só que eu fazia na rua...Dar a eles uma autonomia maior, embora controlada pelos seguranças. É uma integração maior frente ao prédio (N., corretor, 45 anos, morador de Patamares, bairro de perfil médio-alto).

Todas essas questões ligadas à violência têm interferido no padrão de apropriação dos espaços públicos da cidade, que têm os seus usos reduzidos consideravelmente durante a noite, quando Salvador se torna uma cidade quase inóspita ao pedestre. Os parques, praças e largos que possuem grades fecham ${ }^{2}$ e poucos se arriscam neles depois de determinada hora, com algumas exceções. O mesmo acontece com as praias e as principais alternativas de lazer noturno na cidade limitam-se aos shoppings centers e aos bares e restaurantes. Mas, além do medo da violência, os espaços públicos de Salvador são também evitados por motivos associados ao

${ }^{2}$ Mas, como assinalou Serpa (2003, p. 125), “cercar praças é decretar definitivamente a morte destes espaços públicos de uso coletivo. Não podemos pensar num Campo Grande com gradil, como se aquela praça pertencesse apenas aos moradores do entorno". perfil social, às práticas e ao padrão "moral” dos seus frequentadores. Conforme salientou Caldeira (2000), a proteção buscada nos enclaves fortificados ou na evitação dos espaços públicos não se deve apenas à violência, mas também reflete o desejo de não ser incomodado, de manter-se longe dos considerados indesejáveis, da underclass, dos párias urbanos. Essa é uma característica marcante de uma cidade como Salvador.

Os entrevistados, dos mais diversos perfis sociais, apresentaram imaginários restritivos para qualificar os espaços públicos e seus frequentadores, como "baixo astral", lugar que não é "de família”, onde se concentram "maloqueiros", "pessoal com cara de ladrão", "pessoas que não têm muita cultura e dançam até o chão". Muitos deles se referiram constantemente à ideia de que em alguns espaços as pessoas fazem "bagunça/baderna" em contraposição a ambientes mais "familiares". A "falta de educação" existente nesses lugares foi constantemente associada a pessoas de baixa renda, mesmo entre aqueles que auferiam rendimentos baixos e eram moradores de bairros periféricos. Isso indica a existência de estratégias de distinção engendradas não apenas entre diferentes classes, mas também entre estratos de classes ou no interior de uma mesma classe, como, de um lado, uma introjeção da violência simbólica imposta pelos grupos hegemônicos e, de outro, como uma estratégia de fuga desses preconceitos (Bourdieu, 2000, 2007). Tais formas de distinção são complexas e englobam diversos grupos e questões, como aquelas associadas às dimensões de classe, étnico-racial, orientação sexual, estilo, preferência musical etc., como ilustram os seguintes relatos:

Hoje eu não gosto [das festas populares] por causa do acesso, da segurança e uma questão estética. São muitas pessoas feias, independente da cor. É uma questão estética (F., corretor, 42 anos, branco, morador de Piatã, bairro de perfil médio-alto).

Nunca fui muito fã [das festas de largo]. Vou raramente. Acho que tem muita gente. Não tenho vontade de ir. É como um carnaval, uma bagunça, uma bebedeira. Acaba sendo um lugar que mistura muitos segmentos da sociedade e acaba dando muita 
gente feia (B., estudante, 25 anos, branco, morador de Stella Mares, bairro de perfil médio-alto).

[Evito] Hoje em dia ir na Barra, no Farol, nos dias de domingo. Virou um ponto de encontro de gays. Respeito, mas não me sinto à vontade. Tem muitos homossexuais e um não respeita o espaço do outro. [...] Fazem muito barulho, falam palavrões, falam alto. $\mathrm{O}$ jeito de se vestir, falta de respeito. Por exemplo, um casal tá vendo o pôr do sol e eles xingam, procuram palhaçada (G., 18 anos, negro, estudante universitário, morador de Santo Inácio, bairro de perfil popular).

[Sobre os diferentes grupos de jovens existentes na cidade] Talvez o pessoal da suburbana [área de perfil popular] seja diferente, vão para o show de pagofunk baixaria. As meninas se vestem com roupas curtas e decotadas... No meu grupo nós temos um discernimento maior da forma de se vestir (I., 20 anos, negra, estudante universitária, moradora de Plataforma, bairro de perfil popular, com histórico de ascensão social).

Como se vê, estão presentes nessas imagens uma série de preconceitos sociais que se expressa não apenas na evitação dos espaços públicos, mas também em formas de autossegregação, ${ }^{3}$ especialmente entre grupos médios e altos, além de tentativas de controle social dos grupos considerados como indesejáveis. Essa estratificação impacta fortemente as relações de sociabilidade e a autoestima de diversos jovens, em geral negros e de origem popular, que muitas vezes introjetam os preconceitos vigentes na sociedade. Essa dimensão simbólica da segregação (Serpa, 2013) é uma recusa das características da cidade, do inesసี perado, dos encontros fortuitos com o descoN nhecido, da heterogeneidade, da diversidade e do próprio espaço público. Essa é uma quesษ tão que interfere diretamente na vivência mais g profunda do espaço público, conforme defini$\therefore$ do tradicionalmente. Esses comportamentos ‡ estão longe do que Sennett (1988), por exem$\therefore$ plo, chamou da sociabilidade típica da vida pública clássica, um prazer na companhia dos

depoimento de uma entrevistada é claro a respeito dis- so. Ela descreve os motivos pelos quais parou de frequen-

I tar uma boate no Rio Vermelho, bairro boêmio da Orla

U Atlântica que costuma atrair diversos perfis de pessoas:

○ "Inicialmente tinha um pessoal mais educado, depois foi

misturando... caiu o nível do lugar e por isso eu parei de

frequentar” (F., 28 anos, estudante universitária, moradora

$\exists$ da Paralela, região de perfil médio-alto). outros diferentes; estão muito longe também dos ideais de civilidade, como aquilo que protege os homens uns dos outros, ao passo que permite que se tenha prazer nessa companhia (Sennett, 1988). A cultura política autoritária da sociedade brasileira está claramente presente nos relatos anteriores e na prática de diversos grupos, inviabilizando a constituição de um espaço público que se assemelhe ao que Hannah Arendt (2008) definiu como um lugar onde se expressa a pluralidade da condição humana, onde as pessoas interagem e se posicionam através da ação e do discurso.

Esse processo de esvaziamento dos espaços públicos também se expressa na dinâmica atual das festas populares e do carnaval em Salvador, eventos muito importantes na cultura e na dinâmica urbana local. Algumas dessas festas deixaram de existir ou perderam importância e, nos últimos anos, elas têm sido gradativamente abandonadas pelas camadas médias e altas, de modo que os jovens desses grupos sequer as conhecem. Essas transformações, associadas à mercantilização do desenvolvimento urbano incentivaram o surgimento de enclaves fortificados de entretenimento que utilizam a tradição da festa original para a criação de um novo produto, como as festas realizadas em espaços fechados no mesmo dia das festas de largo. Diferentemente da festa popular, as festas fechadas atraem principalmente jovens de camadas médias e altas que querem "curtir" sem precisar conviver com "pessoas feias" (sic) e/ou mesmo socializar com as camadas populares, evitando as festas tradicionais e se autossegregando nesses enclaves. Essas festas ganharam o adjetivo de "light", como o Bomfim Light, realizada no dia da Lavagem da Igreja do Bomfim, e, conforme veiculado numa peça publicitária de um desses eventos, são vendidas como um "privilégio", ou seja, uma clara oferta de segregação e apartação pautada numa espécie de "limpeza" social fundamentada nos altos preços cobrados pelos ingressos.

O auge desses processos de privatização das festas de rua de Salvador ocorre no car- 
naval. Segundo Miguez (2014), o trio elétrico, ao mesmo tempo em que promoveu uma maior democratização da festa na década de 1950, também ampliou sua mercantilização nos anos seguintes, convertendo o carnaval num negócio gerido por grandes corporações. Na passagem dos anos 1980 para os 1990 uma invenção consolidou essa tendência: o aparecimento dos blocos de trio que "privatizam o trio elétrico com suas cordas e reintroduzem uma hierarquia social na ocupação do espaço público da festa” (Miguez, 2014, p. 85). Segundo Moura (2003), embora as cordas não sejam novidade, com o surgimento dos blocos de trio elas passam a avançar contra a multidão, operadas por um gigantesco aparato paramilitar, na busca de mais espaço para seus foliões. Nesse novo contexto, além dos blocos de trio, os camarotes também cumprem um processo importante na privatização da festa, pois, cada dia maiores, também tomam espaço das ruas, espremendo os foliões "pipocas" (aqueles que não estão nem em bloco e nem em camarotes) entre esses espaços e as cordas. Assim, a crescente valorização dos espaços privados e o abandono e evitação dos espaços públicos é uma das marcas da dinâmica urbana contemporânea em Salvador. Não obstante, apesar dessas tendências, não se pode dizer que tais processos anularam os usos dos espaços públicos nesta cidade, já que essa prática continua existindo entre diversos grupos.

\section{USOS DOS ESPAÇOS PÚBLICOS E SOCIABILIDADES URBANAS EM SALVADOR: atores, processos e limites}

A cidade de Salvador contemporânea se oferece aos seus habitantes de maneira desigual e fragmentada, numa espécie de disputa entre a sua geografia de espaços privados e a sua geografia pública, que é formada por um conjunto de espaços programados para uso público, como praças, largos e parques, além das ruas, e espaços naturais, que se convertem em lugares públicos, como as praias por exemplo. Nesse sentido, a geografia de usos e práticas desses espaços assume dimensões distintas entre os diversos grupos sociais e está associada a um conjunto de limitações e especificidades. Uma primeira dimensão relevante é a distribuição desses espaços no território da cidade, que é bastante desigual. Em geral, os espaços públicos se localizam nas áreas mais centrais e no vetor de expansão mais valorizado da cidade. Através da comparação entre a Figura 2, que apresenta os principais

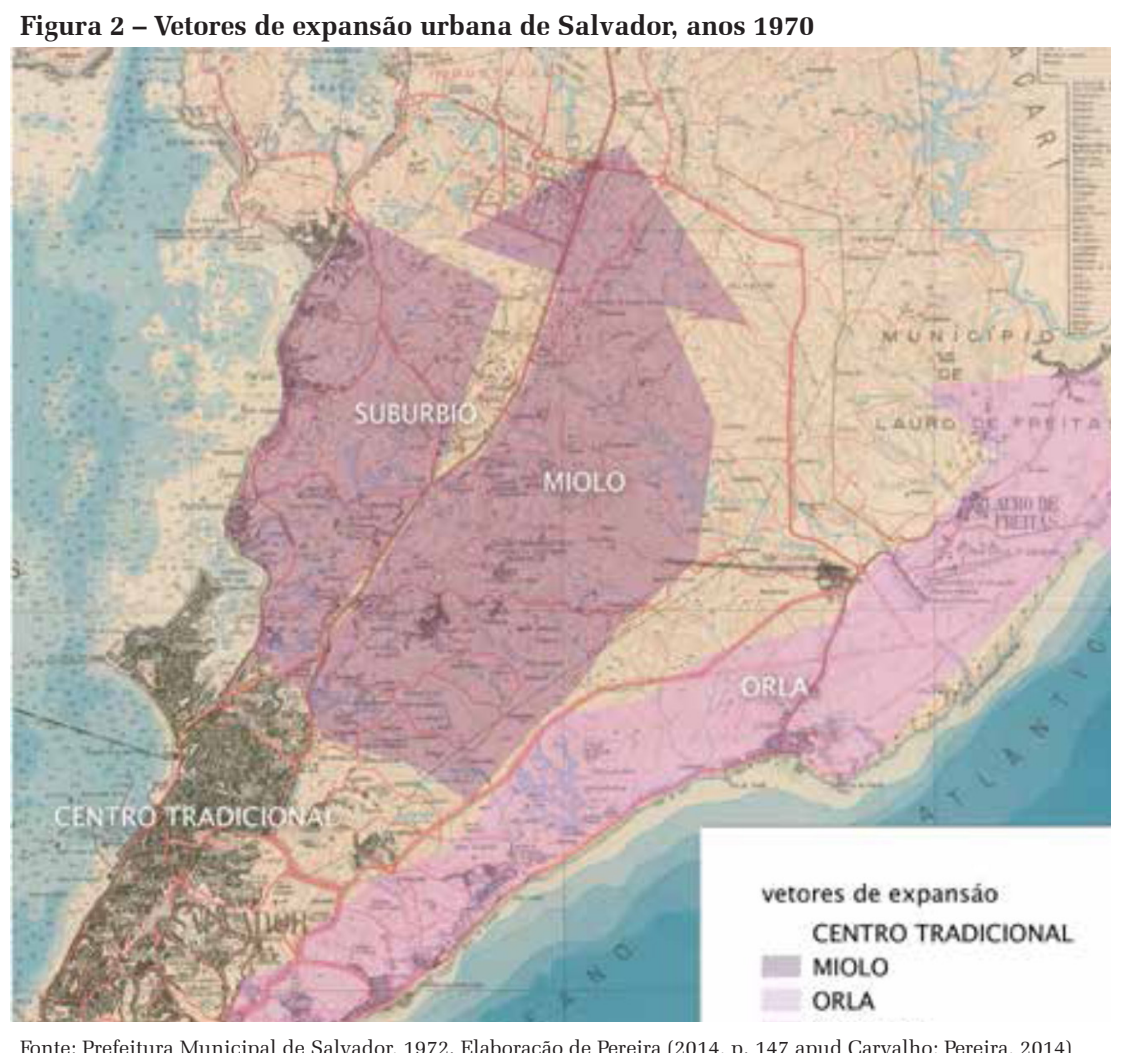

Fonte: Prefeitura Municipal de Salvador, 1972. Elaboração de Pereira (2014, p. 147 apud Carvalho; Pereira, 2014) 
Figura 3 - Parques e Jardins de Salvador, 2015

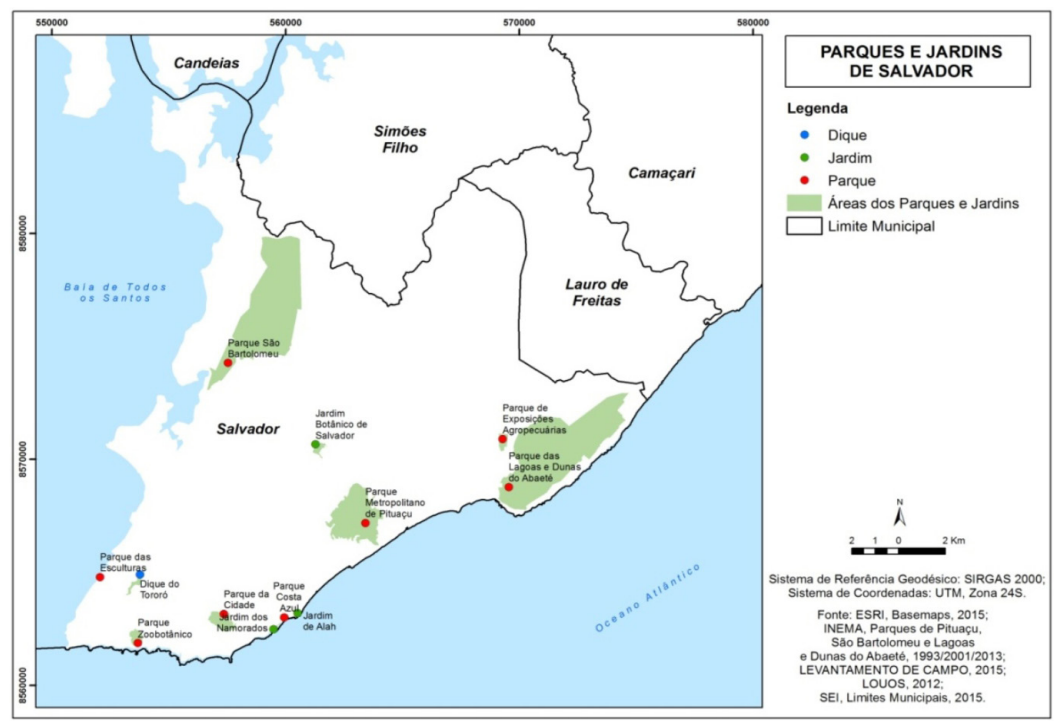

Fonte: LOUOS, 2012; LEVANTAMENTO DE CAMPO, 2015.

vetores de crescimento de Salvador desde a década de 1970 (a Orla Atlântica Norte, reduto de grupos de maior renda, e o "Miolo" e o Subúrbio Ferroviário, que concentram principalmente grupos populares) e as Figuras 3 e 4, que apresentam a distribuição dos parques, jardins, praças e largos de Salvador, é possível identificar a desigualdade intraurbana da geografia pública de Salvador.

Figura 4 - Praças e Largos de Salvador, $2012^{4}$

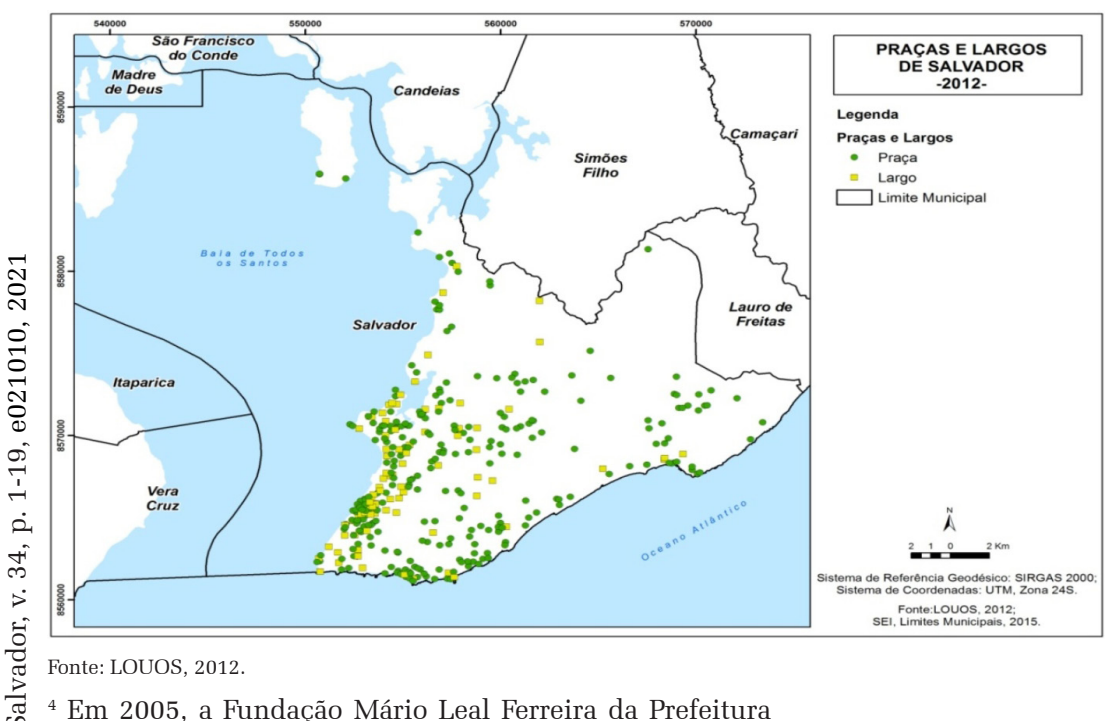

Existe uma desigualdade no acesso aos espaços públicos que se deve tanto a um planejamento urbano que vem historicamente privilegiando determinadas áreas da cidade, quanto a sua incapacidade de diminuir as iniquidades geradas pelo processo de urbanização de Salvador, que foi formada em boa parte por ocupações informais e espontâneas. Ainda que se possa ter o quantitativo desses espaços de uso coletivo, durante muito tempo era difícil saber sua real situação. Como salientou Serpa (2003), muitos acabam sendo espaços ociosos, ornamentos casuísticos do planejamento urbano, sobras de loteamentos que, sem equipamentos, usos ou identidades, podem ser desfeitos em outras obras ou nas próximas divisões da gleba. Por exemplo, a própria Prefeitura Municipal de Salvador (PMS) não possuía, durante a realização da nossa pesquisa, um levantamento atualizado da situação desses espaços, conforme entrevistas realizadas com os setores responsáveis por esses equipamentos. As últimas duas gestões da prefeitura municipal de Salvador (2013-2020), no entanto, deram uma grande ênfase aos projetos de requalificação urbana, desenvolvendo reformas em diversos trechos da orla e também em variadas praças e largos. Notícias recentes da gestão municipal afirmam que foram construídas e/ou reformadas 550 praças em Salvador nesse período (DE- 
SAL..., 2020), o que seria uma ampliação considerável da quantidade desses equipamentos na cidade, tendo em vista o número deles em 2012. ${ }^{5}$

Não só a localização dos espaços programados para uso público interfere diretamente em sua utilização, no perfil dos seus usuários e nas relações de sociabilidade construídas, principalmente por conta dos problemas de mobilidade existentes na cidade. Interfere também nos usos desses espaços e na sua atratividade elementos que superam sua geografia e características físicas (localização, acessibilidade, visibilidade, disponibilidade de equipamentos, arborização, entre outros elementos): o conjunto de disposições à ação, ou habitus, dos usuários, suas identidades e relações grupais (Bourdieu, 2000). Embora exista um contingente significativo de citadinos soteropolitanos que não têm prática (ou evitam) frequentar os espaços públicos da cidade, para diversas pessoas e certos grupos sociais existe um conjunto de práticas e motivos associados à frequência a esses lugares, como atividades físicas, passeios e brincadeiras com as crianças, encontros com os amigos, consumo de bebidas e comidas, eventos, feiras e apresentações musicais, entre outros. A frequência e as práticas em apreço são ilustradas pelos depoimentos que se seguem:

[Frequenta] A Praça de Periperi, a praça de Plataforma. São os espaços de diversidade, então eu acho show de bola, uma galera que tá ali pra se divertir. [...] Uma galera bem jovem de menor idade tá lá também se divertindo. As crianças acabam se divertindo porque tem parque de diversão. Tem o pessoal que vem do trabalho, tem umas meninas que dançam muito bem, liga o carro de som lá. Tem pai, filho, mãe, variações de pessoas. A galera gay também frequenta, o grupo que faz suas apresentações dançando. Uma galera que curte rap, que bota seu

${ }^{5}$ Em 2016 foram promulgadas uma nova LOUOS e um novo Plano Diretor de Desenvolvimento Urbano (PDDU). Nesses instrumentos, os parques urbanos e de bairros e as praças e largos foram incluídos dentro do sistema de áreas de valor ambiental e cultural. Os mapas das referidas leis identificaram 21 parques de bairros e 10 parques urbanos. Porém, as leis e seus documentos anexos não disponibilizaram uma listagem ou mesmo um mapeamento das praças e largos da cidade. carro pra tocar, toma sua cervejinha. Tem a galera do rock, que vem com vinho na mão, e toca seu som pesado nas caixinhas de som que vendem em lojas populares (A, 24 anos, representante comercial/universitário, morador de Plataforma, bairro de perfil popular).

[Frequenta] No meu bairro mesmo. Aquela praça perto do Barradão [São Marcos] que inaugurou há pouco tempo. Tá bastante cheia, é nova. Os amigos vão. [...] Vou comer alguma coisa, beber, passar o tempo. Vou duas vezes no mês. Os amigos às vezes nem marca, chega lá e se encontra. (J., 20 anos, estudante universitário, morador de São Rafael, bairro de perfil médio-popular).

[Frequenta] Praça da Sé, aquela Cruz Caída ali, a Barra [...] Porque é como se fosse um local de encontro do pessoal que mora aqui no Centro e também do pessoal que mora perto do Centro [...] Rapaz, domingo, todo mundo vai pra Barra domingo. Na Praça da Sé é mais passear com alguém, alguma namoradinha, nada de demais... Na Barra a galera vai mais pra passear, se encontrar, o pessoal fica lá tocando violão, conversando, andando de skate às vezes naquela área ali (L., 20 anos, estudante de cursinho, morador do Tororó, bairro de perfil médio-popular).

Ah, praça sim, aqui na frente do meu prédio tem uma praça [Aníbal Jorge, Pituba] [Vai] Quase todo dia, ou eu vou com meu cachorro, fico conversando com os vizinhos, o pessoal aqui é bem unido... Gosto porque todos os vizinhos costumam frequentar e acabou se tornando algo cultural, desde pequena, já tive várias fases né, antes era com as crianças, depois com os adolescentes, agora cada um com seu cachorro, para e fica conversando um tempão, acabou sendo algo social daqui, dessa região, tanto que vem gente de outros prédios que não ficam de frente pra praça que vem pra essa praça aqui porque tem evento, tem festa, tem aniversário de cachorro, tem natal, enfim, é um lugar bem ativo socialmente... (D., 23 anos, estudante universitária, moradora da Pituba, bairro de perfil médio-alto).

Em geral, os espaços públicos utilizados com mais frequência são aqueles próximos das residências dos frequentadores, que fazem deles um uso cotidiano e, frente à diversidade da cidade, mais homogêneo. Eles concentram vizinhos, conhecidos e grupos relativamente semelhantes, se convertendo em territórios do (inter)reconhecimento. Segundo Agier (2011), os citadinos se identificam espontaneamente 
com os lugares mais próximos, construindo uma sobreposição quase perfeita entre o espaço físico e um sentimento de pertencimento a uma coletividade. Por isso, as interações aí desenvolvidas podem ser associadas a relações sociais de tipo comunitário, adotando a definição clássica de Weber (1994, p. 25, grifo do autor), ou seja, um tipo de relação que "repousa no sentimento subjetivo dos participantes de pertencer (afetiva ou tradicionalmente) ao mesmo grupo". Esses padrões de usos dos espaços públicos e de relações de sociabilidade podem ser observados nas mais diversas praças, largos e parques da cidade (Arantes, 2018).

Isso não significa que exista nesses bairros ou nesses espaços públicos uma vida comunitária, harmônica, sem conflitos e medo ou pautada numa homogeneidade absoluta, mas apenas que em termos ideais-típicos os padrões de sociabilidade aí desenvolvidos se assemelham a tais características. Também não significa que entre muitos frequentadores desses espaços não possa se constituir um tipo de prática pautada no compartilhamento do espaço vinculado a uma distância espiritual, como descreveu Simmel (2005). Ainda que os grupos populares (apesar da restrição do número de espaços programados para uso público nesses bairros) e médios de áreas mais tradicionais sejam os principais frequentadores desses espaços de uso cotidiano, mais recentemente as camadas de média e alta renda também têm নิ passado a utilizar alguns deles, principalmente - certas praças reformadas ou adotadas por grandes empresas, ${ }^{6}$ como a Praça Ana Lúcia Magalhães, na cidade de Salvador, por exemplo.

A referida praça se tornou um lugar bastante utilizado, especialmente por jovens casais, seus filhos e "pets", principalmente por ser localizada em uma área elitizada e distante de concentrações populares, além de possuir certa infraestrutura e equipamentos privados

${ }^{6}$ A Prefeitura Municipal de Salvador mantém há bastante tempo um programa chamado Verde Perto, parceria com empresas privadas para manutenção de áreas públicas em Salvador. As empresas escolhem determinadas praças e passam a ser responsáveis pela sua manutenção, arborização etc. para uso infantil (como pula-pula, piscina de bola, minikart, entre outros) e espaços para que as crianças andem de bicicleta, patins, skates, patinetes, miniveículos motorizados etc. A realização de shows e atividades infantis contribui ainda mais para a sua atratividade. Assim como em espaços populares, percebe-se claramente a homogeneidade social dos frequentadores, amplamente brancos e de camadas de média e alta renda. Essa apropriação relativamente homogênea (que demonstra o caráter segregado da cidade) também se expressa em outros espaços que, embora não sejam classificados como programados para uso público, podem ser considerados lugares de acesso público, como as praias. Salvador possui $50 \mathrm{~km}$ de praias de modo que esse atrativo natural desempenha uma espécie de concorrência aos espaços programados para uso público. Pode-se dizer, inclusive, que cumprem um papel mais relevante na cultura soteropolitana como espaços de lazer do que os parques e as praças (Serpa, 2007). Portanto, as praias são alguns dos espaços frequentados por todos os grupos sociais da cidade, mas, assim como os bairros adjacentes a elas, têm um perfil específico de usuários, definidos basicamente em função das linhas gerais de apropriação do espaço da cidade. Tal homogeneidade é reafirmada ainda pelas estratégias deliberadas de localização e circulação, fortemente vinculadas aos estereótipos e imaginários construídos sobre o perfil dos usuários, de modo muito semelhante à lógica utilizada para evitar determinados espaços.

Conforme se observa, ainda permanecem usos diversos dos espaços públicos em Salvador, mesmo que fortemente influenciados pela segregação socioespacial e pelas estratégias de circulação na cidade. Isso contribui para que os largos, parques, praças e praias sejam, em geral, apropriados por grupos sociais semelhantes, o que limita a capacidade desses espaços de expressar diversidade social e engendrar vínculos que construam relações de civilidade, interesse no outro ou mesmo determinadas formas de consenso entre diferen- 
tes classes sociais e estratos de classe, como ocorreria no espaço público tal como definido tradicionalmente (Arendt, 2008; Habermas, 2003; Sennett, 1988). Apesar dessa característica geral, existem exceções relevantes. Alguns espaços públicos em Salvador conseguem agregar usuários de perfis mais diversificados, especialmente aqueles localizados em regiões centrais e valorizadas simbolicamente, como a Praça da Piedade, o Largo do Campo Grande, o Parque do Dique do Tororó e o Farol da Barra. Esses espaços, pela lógica dos usos ordinários, como passagem, ou extraordinários/ocasionais (Agier, 2011), concentram frequentadores diversos como vendedores ambulantes, pessoas em situação de rua, estudantes de colégios e cursos preparatórios para o vestibular, trabalhadores, praticantes de atividades físicas, grupos de idosos, grupos de jovens, artistas de rua, entre outros.

Entre esses espaços, a nova orla do bairro da Barra tem se destacado. Os dados coletados demonstram como o Farol da Barra, especialmente nos finais de tarde e finais de semana, tem se tornado um local de encontro de jovens na cidade, inclusive de moradores de bairros periféricos. Segundo os relatos, isso vem se consolidando desde as reformas realizadas entre os anos de 2014 e 2015. Embora tal reforma tenha gerado muita polêmica pelos efeitos que causou ao bairro, ${ }^{7}$ em todos os momentos em que se realizou observações diretas e participantes, pôde-se notar a presença de muitas pessoas utilizando esse espaço com um perfil variado em termos sociais e de práticas. Em um dos dias do trabalho de campo, por exemplo, pôde-se observar um encontro organizado pelas redes sociais com o nome "Aproveita e me beija", quando uma pluralidade de jovens se fazia presente: pessoas de diversas orientações sexuais, estilos, perfis de roupas (dos "roqueiros" aos "funkeiros" e membros de bondes) e práticas esporti-

\footnotetext{
${ }^{7}$ De acordo com a Associação de Moradores e Amigos da Barra (AMA Barra), as consequências das reformas foram negativas, como a falência de 106 estabelecimentos comerciais, a mudança do trânsito, a falta de vagas de estacionamento, entre outros aspectos.
}

vas, como bicicletas, skates e patins. Alguns relatos ilustram essa configuração do Farol da Barra como um ponto de encontro juvenil de relativa heterogeneidade:

[...] Rapaz, domingo, todo mundo vai pra Barra domingo. [...] Mais de manhã, de tarde... Na Barra a galera vai mais pra passear, se encontrar, o pessoal fica lá tocando violão, conversando, andando de skate às vezes naquela área ali onde a galera anda de skate. [Tinha] Adolescentes entre 16 e 20 anos. E turistas também, muito turista... Um perfil social alternativo, aquela galerinha alternativa, da maconha, do rock, do reggae, da cachaça que você vê muita gente bebendo ali, virou point de cachaça na verdade aquilo ali. [As pessoas] Interagem, aí sim interagem. Tem até eventos ali, alguma coisa do abraço e do beijo, aí fica um grupinho lá se abraçando, se beijando. [...] tem muita gente dos outros bairros mesmo, no geral, não é só o pessoal do centro não (L., 20 anos, estudante de cursinho, morador do Tororó, bairro de perfil médio-popular).

[...] Querendo ou não se tornou meio que um evento você ir na Barra domingo, mesmo você não morando na Barra. Eu vejo muita gente indo, eu mesmo passei uns dois meses indo todo domingo lá, final de tarde (D., 23 anos, estudante universitária, moradora da Pituba, bairro de perfil médio-alto).

Algumas praias, como o Porto da Barra, também se configuram como exceções à tendência mais geral de reafirmação do padrão de apropriação social do espaço da cidade sobre os usos dos espaços públicos. Nesses espaços mais plurais, diferentemente do que acontece nos espaços de usos e perfis mais homogêneos, os padrões de sociabilidade construídos se baseiam em outros fundamentos. Em geral, as observações realizadas e os relatos colhidos indicam que, com raras exceções, os padrões de interação desenvolvidos se constroem em torno do que Simmel (2005) identificou como uma espécie de indiferença e, especialmente, proteção frente aos outros. Dificilmente há interações mais duradouras e/ou "profundas" entre as pessoas, para além de um contato visual ou um rápido comentário sobre algo corriqueiro. Como Sennett (1988) descreveu no processo que chamou de diluição do comportamento público em Londres e Paris, prevalece muitas 
vezes a ética do silêncio na utilização desses espaços. Isso é típico de certos usuários, principalmente aqueles que têm nos espaços públicos um lugar de práticas individuais, como os esportistas. Em tempos de aparato eletrônico, isso fica muito visível na utilização dos fones de ouvido que, simbolicamente, representam o recado de que não se está disposto a dialogar.

Os relatos coletados indicam que dificilmente as pessoas constroem novas relações frequentando espaços públicos, principalmente porque, quando o utilizam, já estão acompanhados dos próprios amigos, namorados(as) ou familiares e, quando muito, conhecem "amigos de amigos". Nesse aspecto, os entrevistados foram muito diretos, destacando que tanto nos parques e praças quanto nas praias dificilmente há formas de interação entre os distintos grupos de usuários, com exceção dos momentos "de paquera”, quando as interações intergrupais se ampliam. Na prática, portanto, as interações têm um perfil intraclassista, mesmo nos espaços públicos, não apenas por uma questão de acessibilidade e localização dos espaços, mas também por conta dos habitus, estilos e interesses dos diversos grupos. É interessante notar como os entrevistados relatam um tipo de interação pautada numa autossegregação dos grupos, conforme salientado por Serpa (2013).

Tais espaços de diversidade se convertem em lugares fragmentados, marcados por estratégias de neutralização das diferenças. A exceção $\vec{\delta}$ a essa prática é dada pelo comportamento das : crianças, alguns grupos de jovens (como aqueles do Farol da Barra) e idosos que, por serem ¿ aposentados e possuírem mais tempo livre, reúoิ nem-se muitas vezes nos espaços públicos. Esi. ses grupos desenvolvem alguns jogos de sociaले bilidade baseados na vontade de participar, ou $\vec{\Delta}$ seja, uma forma de socialização sem quaisquer propósitos, interesses ou objetivos além da interação nela mesma (Simmel, 2002). Mas o padrão mais frequente de sociabilidade se aproxima das compreensões de Simmel (2005) sobre a vida nas grandes metrópoles: a constituição de contatos superficiais, transitórios e segmen- tados derivada da heterogeneidade de pessoas, situações e vivências existentes.

Serpa (2013) evita classificar esse padrão interacional como típico de um espaço verdadeiramente público, pois essa apropriação se dá através do autoisolamento de grupos e indivíduos que negam o outro através da indiferença, fazendo do público um território privado, onde a vida doméstica se desnuda ao olhar de todos, o que esvazia a sua dimensão política. Por esta interpretação, a diluição e/ou restrição dos espaços públicos pode ocorrer não apenas através do seu abandono e evitação, mas também justamente por meio dos tipos de usos e práticas que se dão nesses espaços. Autores como Joseph (1999), Bordreuil (2002) e Sabatini et al. (2013), por outro lado, reconhecem que esses comportamentos, baseados na "vulnerabilidade dos compromissos” (Joseph, 1999, p. 36), parecem ser característicos dos espaços públicos de sociedades complexas e, ao contrário de serem somente limitadores, possuem também o potencial de engendrar a liberdade de movimentos e garantir a existência das diferenças, produzindo determinado tipo de hospitalidade baseada no acolhimento e na ausência de controles que garantiria a liberdade individual e a existência das diferenças.

Nesse sentido, mesmo que não produza vínculos ou não seja permeada de interações propriamente "políticas", a copresença nesses espaços poderia significar a produção de contatos, também importantes para a coesão social na medida em que dão forma à dimensão fortuita da vida de uma cidade, vez que podem transformar imaginários e reconstruir preconceitos e estereótipos (Sabatini et al., 2013). Frente a um contexto em que as formas de segregação e autossegregação são cada vez mais extremas e o abandono e evitação dos espaços públicos se torna uma tendência, tais contatos ganham ainda mais importância porque permitem que a diversidade se expresse de alguma forma. Desse modo, ainda que de modo fragmentado, a cidade pode expressar sua realidade e contradições “[...] entre esplendor e miséria, entre riqueza 
e pobreza, inteligência e ignorância, ordem e caos" (Wirth, 1979, p. 103).

Além dos usos dos espaços públicos referidos até agora, outros dois assumem também um papel relevante na cidade de Salvador: os usos rituais e festivos e os políticos. Apesar de premidos pelas tendências de privatização e fortificação, várias festas populares de largo e o carnaval continuam tendo forte relevância. Nesses momentos o espaço urbano expressa as sociabilidades existentes, não ausentes de conflitos e de reivindicações, pois, ao mesmo tempo em que são festas, no sentido mais literal do termo, se configuram também como uma ocupação política dos espaços da cidade, vez que são marcados pela presença de diversificados grupos cultural e politicamente organizados. De certa forma, os espaços da cidade do Salvador também têm sido apropriados para fins políticos, como em outras cidades no mundo onde o espaço urbano se converteu em lócus de reunião para articulação de queixas e exigências coletivas (Harvey, 2014). Além de formas mais tradicionais, como protestos e atos públicos, destacam-se cada vez mais os piquetes e fechamento de ruas e avenidas, muitas vezes com queima de pneus e outros materiais, especialmente em casos mais sensíveis, geralmente ligados à violência policial. Apesar da relevância dessas manifestações e de sua apropriação dos espaços públicos, assim como os demais usos, estes são também bastante fragmentados, uma vez que são realizados geralmente por grupos específicos e expressam os conflitos de uma cidade desigual e segregada.

Pelo que se pôde observar nesta seção, os usos dos espaços públicos e as relações nele desenvolvidas são bastante diversificados e complexos, como não poderia deixar de ser em uma sociedade desigual e fragmentada como Salvador. Eles apresentam múltiplas marcas de mercantilização e privatização, segregação e exclusão, mas também contratendências e resistências, especialmente dos grupos políticos.

\section{O(S) ESPAÇO(S) PÚBLICO(S) SO- BREVIVE(M) DESIGUAIS, SEGRE- GADOS E FRAGMENTADOS}

A preocupação com os usos do(s) espaço(s) público(s) na vida urbana contemporânea, analisados aqui através da experiência da cidade de Salvador, expressa a necessidade de compreender as características das cidades contemporâneas e seus processos de transformação nas últimas décadas, especialmente comparadas àquelas características identificadas como típicas das cidades modernas, aparentemente marcadas pelos "[...] encontros, confrontos das diferenças, conhecimentos e reconhecimentos recíprocos (inclusive no confronto ideológico e político) dos modos de viver [...]" (Lefebvre, 2008, p. 22). Frente às teses sobre o "fim ou morte dos espaços públicos", este trabalho fornece elementos para o debate. As evidências coletadas sobre a dinâmica da vida urbana de Salvador contemporânea demonstram claramente uma tendência de esvaziamento e restrição dos espaços públicos, ou seja, o aprofundamento de tendências antes esboçadas e a proliferação de novas lógicas de autossegregação e privatização. Isso é expresso principalmente pelo abandono e pela evitação cada vez mais comuns dos espaços públicos e pela crescente valorização dos espaços privados, que centralizam a experiência urbana de boa parte dos citadinos.

Mesmo com tal tendência, os usos dos espaços públicos conservam certa vitalidade e fazem parte das práticas de diversos grupos. Os espaços públicos disponíveis em Salvador são heterogêneos entre si e por isso bastante desiguais, em termos de condições, usos e localização. Em geral, os usos mais cotidianos desses espaços são segregados no sentido de que não logram produzir convivência entre diferentes grupos. Isso ocorre tanto em espaços públicos de bairros populares quanto em algumas praças que têm sido recentemente apropriadas por grupos de maior poder aquisitivo, se convertendo em espaços bastante elitizados. Situação semelhante ocorre nas praias, 
que também são segregadas em função da sua localização e do perfil de classe predominante entre os usuários. Apesar dessa característica mais geral, alguns espaços agregam usuários de perfis mais diversificados, em termos de classe, raça e de práticas culturais. Em geral, são lugares simbolicamente relevantes e/ou se localizam em regiões mais centrais. Os espaços da cidade são ainda utilizados em momentos rituais e festivos, como as festas tradicionais de largo e o carnaval, e como lócus de mobilização e participação política.

Nesses espaços mais plurais, no entanto, os encontros tendem a ser superficiais, transitórios e segmentários (Simmel, 2005), expressando-se muitas vezes em formas de autossegregação dos grupos de usuários (Serpa, 2013). Na prática, portanto, as interações têm perfil intraclassista, não apenas por uma questão de acessibilidade e localização dos espaços, mas também por conta dos habitus, estilos e interesses dos diversos grupos. A negação da diferença, condição fundamental do espaço público, indica que a vida dos citadinos em Salvador, de maneira geral, é construída em torno de círculos e circuitos bastante específicos. E isso interfere na apreciação do outro, na disposição ao encontro e nos usos dos espaços públicos, assim como na existência de diversificadas formas de conflito, disputas por espaço, formação de territórios "morais" e simbólicos. Mesmo com existência dessas práticas ন de autoisolamento, é relevante destacar que, - frente a um contexto urbano em que formas cada vez mais extremadas de segregação se \& ampliam, o simples contato entre as pessoas $\rightarrow$ produzido pelos espaços públicos pode ajudar $\dot{2}$ a desconstruir alguns estigmas e estereótipos.

ले Apesar da reafirmação da lógica mais $\vec{i}$ ampla da segregação e das desigualdades nos usos dos espaços públicos de Salvador, os grupos populares parecem estar quebrando determinadas barreiras, especialmente em seus circuitos de uso, ampliando a sua visibilidade em diversos espaços antes não acessíveis. Seus circuitos parecem ser mais amplos (no sentido geral da cidade) do que os dos grupos médios e altos, pois estes basicamente se autossegregam em espaços privados, praias específicas e, eventualmente, determinadas praças bastante homogêneas. Como se observa, muitos são os dilemas associados aos usos dos espaços públicos e analisá-los, como advertido por Andrade e Baptista (2013), exige do pesquisador um cuidado muito grande no seu entendimento e distinção, pois eles expressam uma diversidade de experiências e apresentam tendências múltiplas, muitas vezes contraditórias. Em Salvador ficou patente como se desenvolvem processos de esvaziamento e restrição dos espaços públicos, principalmente, no comportamento das camadas médias e altas que se autossegregam em enclaves fortificados e espaços exclusivos, onde a sociabilidade é homogênea. Enquanto isso, as camadas populares utilizam os espaços públicos de maneira mais ampla, porém concentradas em seus próprios bairros e em áreas de perfil semelhante. São poucos os espaços de convivência interclassista, que servem como palco para a construção de padrões de sociabilidade relativamente restritivos, uma vez que não há interações mais profundas entre os distintos grupos, para além de contatos visuais. Nesta cidade, os espaços públicos não cumprem o papel assignado teoricamente como lugar integrador e gerador de práticas democráticas (Ramírez-Kuri, 2008).

Assim, em Salvador o espaço público não está morto, pois conserva certa vitalidade, mas se caracteriza, como seria de se esperar pelas condições da própria cidade, por seu caráter extremamente desigual, segregado e fragmentado. Nesse aspecto, o caso de Salvador, mesmo com suas especificidades, não parece ser diferente de outras cidades brasileiras e latino-americanas e é provável que tais características se repitam também nesses contextos.

Recebido para publicação em 29 de junho de 2018. Aceito em 23 de dezembro de 2020. 


\section{REFERÊNCIAS}

AGIER, M. Antropologia da cidade: lugares, situações, movimentos. São Paulo: Terceiro Nome, 2011.

AMENDOLA, G. La ciudad postmoderna: magia e miedo de la metrópolis contemporánea. Madrid: Celeste, 2000.

ANDRADE, L. T.; BAPTISTA, L. P. Espacos públicos: interações, apropriações e conflitos. In: CONGRESSO LATINO-AMERICANO DE SOCIOLOGIA, 19., 2013, Santiago do Chile. Anais [...]. Santiago do Chile: ALAS, 2013.

ARANTES, R. A. Fugindo dos "males" da cidade: os condomínios fechados na grande Salvador. 2011. Dissertação (Mestrado em Ciências Sociais) Universidade Federal da Bahia, Salvador, 2011.

Inter-reconhecimento, diversidade autossegregação: formas de sociabilidade nos espaços públicos de Salvador. In: BÓGUS, L. M. M.; GUIMARÃES, I.; PESSOA, Z. S. (org.). Cidades no século XXI: temas em debate. São Paulo: Educ, 2018. p. $23-34$.

$\mathrm{O}(\mathrm{s})$ espaço(s) público(s) na cidade capitalista da cidade que liberta ao declínio do homem público. Estudos de Sociologia, Recife, v. 1, n. 25, p. 111-138, 2019.

ARENDT, H. A condição humana. Rio de Janeiro: Forense Universitária, 2008.

BAUMAN, Z. Confiança e medo na cidade. Rio de Janeiro: Jorge Zahar, 2009

BORDREUIL, S. Espace public, urbanité et mouvements. In: JOLÉ, M. (coord.). Espaces publics et cultures urbaines : actes du séminaire du CIFP de Paris 20002001-2002. Lyon: Certu, 2002. p. 45-68.

BOURDIEU, P. A distinção: crítica social do julgamento. São Paulo: Edusp; Porto Alegre: Zouk, 2007.

$O$ poder simbólico. 3. ed. Rio de Janeiro: Bertrand Brasil, 2000.

CALDEIRA, T. P. R. Cidade de muros. São Paulo: Edusp, 2000.

CARVALHO, I. M. M.; PEREIRA, G. C. (org.). Salvador: transformações na ordem urbana. Rio de Janeiro: Letra Capital: Observatório das Metrópoles, 2014.

DAMMERT, L. Santiago de Chile: segregación y cotidianidad del temor. In: NOYOLA, J.; DE MATTOS C. A.; ORELLANA, A. Urbanización en tiempos de crises: impactos, desafíos y propuestas. Santiago de Chile: Pontifícia Universidad Católica de Chile, 2013. p. 383-414.

DAVIS, M. Cidade de quartzo. São Paulo: Boitempo, 2009.

DESAL produziu mobiliário para 450 praças em sete anos. Desal, Salvador, 5 nov. 2020. Disponível em: http:// desal.salvador.ba.gov.br/index.php/noticias/1569desal-produziu-mobiliario-para-450-pracas-em-seteanos. Acesso em: 23 dez. 2020.

DUHAU, E. Las metrópolis latinoamericanas en el siglo XXI: de la modernidad inconclusa a la crisis del espacio público. Cadernos IPPUR, Rio de Janeiro, n. 1, p. 41-68, 2001

FRÚGOLI JR., H. Sociabilidade urbana. Rio de Janeiro: Jorge Zahar, 2007.

GOMES, P. C. C. A condição urbana: ensaios de geopolítica da cidade. Rio de Janeiro: Bertrand Brasil, 2008.
HABERMAS, J. Mudança estrutural da esfera pública. Rio de Janeiro: Tempo Brasileiro, 2003.

JOSEPH, I. Espace public, urbanité, citoyenneté. In: JOLÉ, M. (coord.). Espaces publics et cultures urbaines: actes du séminaire du CIFP de Paris 2000-2001-2002. Lyon: Certu, 2002. p. 33-44.

Paisagens urbanas, coisas públicas. Caderno $\overline{C R H}, \bar{S}$ Salvador, n. 30, p. 11-40, 1999.

LEFEBVRE, H. O direito à cidade. São Paulo: Centauro, 2008.

LEITE, R. P. Espaços públicos na pós-modernidade. In: LEITE, R. P.; FORTUNA, C. (org.). Plural de cidades: novos léxicos urbanos. Coimbra: Almedina, 2009. p. 187-204.

MIGUEZ, P. Carnaval da Bahia: do entrudo lusitano aos desafios contemporâneos. In: RIBEIRO, M. A.; ARNAULT, A. P. (org.). Viagens do carnaval: no espaço, no tempo, na imaginação. Salvador: EDUFBA, 2014. p. 73-93.

MONGIN, O. A condição urbana: a cidade na era da globalização. São Paulo: Estação Liberdade, 2009.

MOURA, M. Um mapa político do carnaval: uma reflexão a partir do caso de Salvador. In: ESTEVES JÚNIOR, M.; URIARTE, U. M. (org.). Panoramas urbanos: reflexões sobre a cidade. Salvador: EDUFBA, 2003. p. $93-106$.

NETTO, V. A urbanidade como devir do urbano. In: AGUIAR, D.; NETTO, V. (org.). Urbanidades. Rio de Janeiro: Folio Digital: Letra e Imagem, 2012. p. 33-59.

PAQUOT, T. L'espace public. Paris: La Découverte, 2009.

PEREIRA, L. M. L. Relatos orais em ciências sociais: limites e potencial. Análise \& Conjuntura, Belo Horizonte, v. 6, n. 3, p. 109-127, 1991.

PEREIRA, M. G. Filhos e cidade: narrativa sobre a significação da cidade por pais que moram em condomínios fechados de alto padrão. 2013. Dissertação (Mestrado em Psicologia Cultural) - Universidade Católica do Salvador, Salvador, 2013.

PRADO JÚNIOR, C. Formação do Brasil contemporâneo. São Paulo: Brasiliense, 2008.

RAMÍREZ-KURI, P. La fragilidad del espacio, público en la ciudad segregada. In: CORDERA, R.; RAMÍREZ-KURI, P.; ZICCARDI, A. Pobreza, desigualdad $y$ exclusión social en la ciudad del siglo XXI. Ciudad de México: Siglo XXI, 2008. p. 117-134.

SABATINI, F. etal. (ed.). Cultura de cohesión e integración social en ciudades chilenas. Santiago de Chile: Pontificia Universidad de Chile, 2013.SALVADOR. LEI $N^{o}$ 8.167/2012. Dispóe sobre a Lei de Ordenamento do Uso e da Ocupação do Solo do Município de Salvador e dá outras providências. Disponível em http://www. sucom.ba.gov.br/wp-content/uploads/2016/08/corpo lei 8167 2012.pdf. Acesso em 17/09/2015, às 15:23h.

SALCEDO HANSEN, R. El espacio público en el debate actual: una reflexión crítica sobre el urbanismo postmoderno. EURE, Santiago de Chile, v. 28, n. 84, p. 5-19, 2002 .

HARVEY, D. Cidades rebeldes: do direito à cidade à revolução urbana. São Paulo: Martins Fontes, 2014.

SENNETT, R. O declínio do homem público: as tiranias da intimidade. São Paulo: Companhia das Letras, 1988.

SERPA, A. Apropriação social versus requalificação dos parques e praças na capital baiana. In: ESTEVES JÚNIOR, M.; URIARTE, U. M. (org.). Panoramas urbanos: reflexões sobre a cidade. Salvador: EDUFBA 2003. p. 121-139. 
. O espaço público na cidade contemporânea. Sã̃o Paulo: Contexto, 2007.

. Segregação, território e espaço público na cidade contemporânea. In: VASCONCELOS, P. A.; CORREA, R. L.; PINTAUDI, S. M. (org.). A cidade contemporânea: segregação espacial. São Paulo: Contexto, 2013. p. 169188.

SIMMEL, G. As grandes cidades e a vida do espírito. Mana, Rio de Janeiro, v. 11, n. 2, p. 577-591, 2005.

Cuestiones fundamentales de sociología. Barcēlona: Gedisa, 2002.
STRAUSS, A.; CORBIN, J. Pesquisa qualitativa: técnicas e procedimentos para o desenvolvimento da teoria fundamentada. Porto Alegre: Artmed, 2008.

WEBER, M. Economia e sociedade. Brasília, DF: Editoria da UnB. 1994. v. 1.

Economia e sociedade. Brasília, DF: Editoria da UnB; São Paulo: Imprensa Oficial do Estado de São Paulo, 1999. v. 2.

WIRTH, L. Urbanismo como modo de vida. In: VELHO, O. G. O fenômeno urbano. 4. ed. Rio de Janeiro: Zahar, 1979. p. $90-113$. 


\section{THE PUBLIC SPACE(S) IN AN UNEQUAL AND SEGREGATED CITY}

\section{Rafael de Aguiar Arantes}

This article analyzes the uses of the public spaces in the contemporary urban life, discussing their relevance and ability to express diversity and produce intersubjectivities. For that, it discusses the validity of the thesis indicating the existence of a dilution/restriction process of public spaces. Through literary review, secondary data collection, and interviews with city residents, this work sought to analyze the dynamics of public spaces in Salvador before the recent urban transformations in the city. The findings indicate that the contemporary transformations favored privatization and selfsegregation, restricting the use of public spaces. However, one cannot speak of the "death" of public spaces in Salvador, for their uses survives - although pressed by several factors such as their heterogeneity and inequality, their segregated and fragmented character, and by privatization and commodification processes, violence and fear, forms of disputes, distinctions and competitions.

KEYwords: Public space. Urban Sociability. Privatization. Segregation. Salvador.

\section{LE(S) SPACE(S) PUBLIC(S) DANS UNE VILLE INÉGALE ET SÉGRÉGÉE}

\author{
Rafael de Aguiar Arantes
}

Cet article analyse l'utilisation des espaces publics dans la vie urbaine contemporaine, en discutant sa pertinence actuelle et sa capacité d'exprimer la diversité et créer d'intersubjectivités. Cela implique discuter la validité des thèses qui indiquent l'existence d'un processus de dilution/restriction des espaces publics, en analysant sa dynamique dans la ville de Salvador, et en considérant les récentes transformations urbaines, par l'examen de la littérature, la collecte des données secondaires et des entretiens avec plusieurs habitants. On conclut que les transformations contemporaines ont favorisé l'avancée des formes de privatisation et d'auto-ségrégation, restreignant les usages des espaces publics. Cependant, ces espaces publics à Salvador ne sont pas mort ; leurs usages survivent, même s’ils sont pressé par leur caractère hétérogène, inégal, ségrégé et fragmenté, situation causée par les processus de privatisation et de marchandisation, la violence et la peur, en plus de différentes formes de disputes, distinctions et compétitions.

Mots-clés: Espace public. Sociabilité urbaine. Privatisation. Ségrégation. Salvador.

Rafael de Aguiar Arantes - Mestre e Doutor em Ciências Sociais pela mesma Universidade, com estágio
de doutoramento no Instituto de Estudios Urbanos y Territoriales da Pontificia Universidad Católica de
Chile. Atualmente é professor adjunto do Departamento de Sociologia, do Programa de Pós-graduação
em Ciências Sociais e do Mestrado Profissional em Segurança Pública, Justiça e Cidadania da UFBA.
É pesquisador associado ao Centro de Estudos e Pesquisas em Humanidades - CRH/UFBA e ao núcleo
Salvador do INCT/Observatório das Metrópoles. Tem experiência de pesquisa, com ênfase em Sociologia
Urbana, atuando principalmente nos seguintes temas: metrópoles latino-americanas, segregação e
desigualdades sócio-espaciais, espaço público e sociabilidade urbana. 
